\title{
Revisiting Texts and Defining Cultural Identity: Exploring Intertextuality in Chang-Rae Lee's Articulation of the Korean- American Cultural Experience in Native Speaker
}

\section{* Olfat Nour El-Din Kerney Mohammad Yussef}

\begin{abstract}
Intertextuality equips writers with the power to revisit texts and to present them in a new attire. The selection of the integrated texts and the transformation brought about them offer much insight into the writer's ideological agenda. In this study, intertextuality is explored as a tool for investigating the cultural experience painted in Chang-Rae Lee's Native Speaker. The novel explores the Korean marginalized identity within the white-dominated American society. Lee's instances of intertextuality can be grouped under four main categories: The Whitmanian preface, Shelley's poem, the Korean folksong and the use of the Korean language. The investigation of these instances attempts to shed light on the reasons for revisiting these texts and how they help in constructing the KoreanAmerican cultural experience.

Results: Lee's revisiting of the American and the British canonized classical works, the Korean folksong and the Korean Language system reflect the struggle with hybrid identity. At the end, the protagonist reaches the conclusion that he is a product of both cultures and that he needs to be accepted as a hybrid rather than a pure Korean or a pure American.

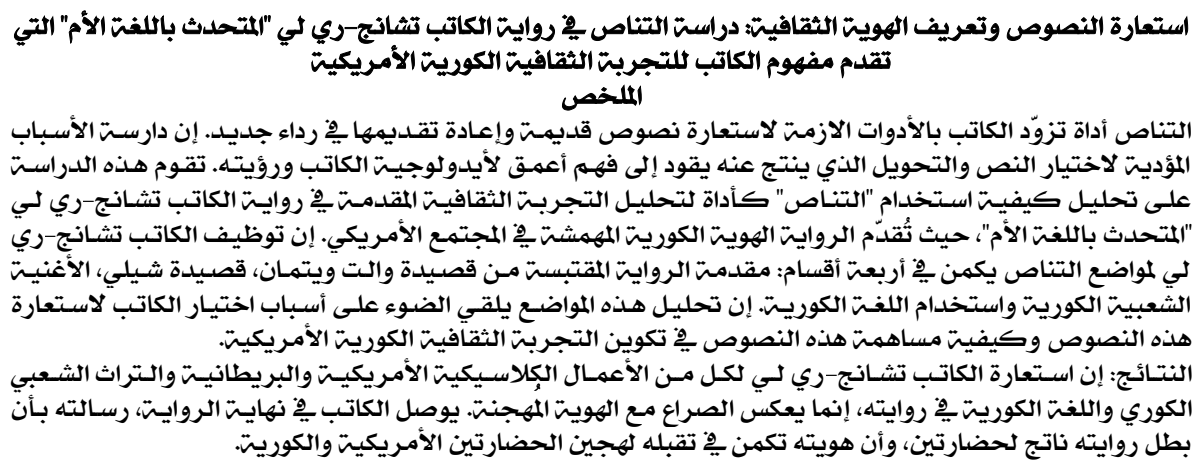

A PhD Candidate at Helwan University, The Faculty of Arts, English Department 


\section{Introduction}

Intertextuality equips writers with power to "mix writings", "to counter the ones with the others" (Barthes \& Heath, 1977, p.146), and to borrow from other texts and language systems the necessary linguistic tools that would enable them to express their own vision of the world. Kristeva (1980) argues that intertextuality "has nothing to do with matters of influence by one writer upon the other, or with the sources of a literary work" (p.15); instead it is the product of a writer's selection from a huge corpus of words, phrases, sentences, genres and plots. Accordingly, a writer's revisiting of texts is "accompanied by a new articulation of the enunciative and denotative position" brought about by the new text (Kristeva, 1980, p.15). In this way, exploring intertextual instances helps understand a writer's interpretation of a previously uttered text. Thus, intertextual integration can be a tool of investigating a writer's ideology toward the revisited texts and their function in the new text.

In this study, intertextuality is explored as a tool for investigating the cultural experience painted in Chang-Rae Lee's Native Speaker. The novel explores the Korean marginalized identity within the dominant American society. The cultural clash, the language barriers and the identity struggle are reflected in Lee's employment of intertextuality.

\subsection{Intertextuality}

The term 'intertextuality' was introduced by the Bulgarian-French linguist and critic Julia Kristeva in the late 1960s. Her theory of intertextuality is very much influenced by Saussure's (1959) view of language as a differential system of signs and Bakhtin and Medvedev's (1978) stress on the historical and social factors resulting in the different utterances. To illustrate, for Saussure, language is a system of signs where users select their acts of communication from a vast system of language structures. Allen (2000) summarizes Saussure's view of language,

When humans write or speak, they may believe they are being referential, but in fact, they are producing specific acts of linguistic communication (parole) out of the available synchronic system of language (langue). The reference of the sign is to the system, not directly to the world. (p.9). 
Thus, language as a communicative tool is rather differential than referential. That is, as users of language engage in communicative acts, their language production is based on a process of selecting lexical items and syntactic structures from the differential possibilities offered by the language system. This differential aspect of language is the origin of intertextual theory; just as language users select from the vast differential language system, writers "select plots, generic features, aspect of characters, images, ways of narrating, even phrases and sentences from previous literary texts and from the literary tradition" (Allen, 2000, p.11). In this way, a text is "a multidimensional space in which a variety writing, none of them original, blend and clash" (Barthes \& Heath, 1977, p.146).

Furthermore, Bakhtin and Medvedev (1978) add the historical and social dimension of language, which also contributes to a better understanding of intertextuality. They claim that language production is bound to its historical and social function. Any individual utterance must be associated with the "the historical moment" or the "here and now" (Bakhtin \& Medvedev, 1978, p.120) of the utterance and the social conditions giving rise to it. By applying this view to intertextuality, it can be argued that as writers choose to integrate previously uttered pieces of language, the social and the historical factors of the new utterance impose a new interpretation upon this new production.

Building on this, Kristeva (1986) introduces intertextuality as "a mosaic of quotations", regarding text as "the absorption and transformation of another" (p.37). This transformation is bound by the social and historical positioning of the new text. Thus, looking at the intertextual instances of the text is mainly concerned with how the revisited text functions in the new context and how it reflects the writer's ideological associations and interpretations. "In this sense, the text is not an individual, isolated object but, rather, a compilation of cultural textuality" (Allen, 2002, p.36).

\subsection{Cultural Studies and Identity}

Investigating culture is the core of cultural studies. While the object of study is clear, the approach to cultural studies cannot be as evident. Hartley (2003) argues that "[t]he object of study in cultural studies changed over time ... This was not only a matter of deciding what was meant by culture ... , but also a question of the analytical agenda" (p. 8). 
Investigating culture has covered a wide spectrum ranging from gender and ethnicity to postcolonialism. Nevertheless, despite the different objectives, cultural studies is distinguished as a field of inquiry. He further captures the development of cultural studies as he introduces how cultural studies started as an umbrella field that grouped different subjects. He labels cultural studies "a philosophy of plenty" (Hartley, 2003, p. 10). Barker (2002) summarizes the role of cultural studies by stating that its definition, objective and methodology lie not in the view of cultural studies as a single object of study but rather an investigation of the different world perspectives stemming from the different values and ideologies.

Additionally, Eagleton (2000) argues that it is very difficult to investigate a culture from within. He states that "every culture has an internal blindspot where it fails to grasp or be at one with itself, and to discern this ... is to understand that culture more fully" (p. 96). He, thus, calls for an intercultural communication. This interrelation can be attained through the study of minorities as they share their experience in a world dominated by another major culture. Culler (2000) maintains that "work in cultural studies has been particularly attuned to the problematic character of identity and to the multiple ways in which identities are formed, experienced, and transmitted" (p. 45). Cultural studies seeks the investigation of marginalized cultures where the identities of ethnic minorities, women and immigrants are highlighted against the dominant culture they exist in. Thus, identity becomes a primary tool in approaching cultural studies.

Culler (2000) introduces identity as the question of the self 'what is it that I am' and 'what makes it what it is' (p. 109). He argues that literary theory often raises two questions regarding identity. The first question asks whether the self is something made or given; the second asks whether identity of the self should be perceived individually or socially. A combination of these options are what sets the trends in discussing identity in literature.

Thus, in this study, a cultural study is attempted by looking at the marginalized identity of the Korean-American against the dominant American culture. The analysis will be conducted by exploring how Chang- 
Rae Lee revisits classical texts and integrates the Korean language system to produce his own vision of his cultural identity in his fictional narrative Native Speaker.

\section{Native Speaker}

Native Speaker is a first-person narrative that tells the story of the Korean-American Henry Park. The novel focuses on three aspects of his life: his relationship with his American wife, Lelia, his job at the commercial spy agency and his relationship with his Korean family, especially his father. The relationship Henry maintains with his father and his memories of his parents, in general, set the background in which he was raised. His upbringing in a Korean environment leads to his conflicted identity, which is different from the mainstream American one. Henry works at a spy agency that makes use of his ethnic origin to spy against targets who pose potential threats to their American clients. For his new assignment, Henry accepts a job to spy on a successful Korean-American senator who is running for mayor. This job highlights Henry's conflict with identity. The job raises the question of where he truly belongs: to his original Korean roots, or to the dominant American society.

\section{Analysis}

Umberto Eco (1979) maintains that no "text is read independently of the reader's experience of other texts" (p. 21). This is very much applicable to Lee's Native Speaker where many instances of intertextuality take place. Because Lee's discourse is viewed as a presentation of the marginalized identities in America, reference to other texts should be very significant. Chevereşan (2013) argues that Native Speaker "plays upon the definition of sameness and otherness, upon alternative ideas of Americanness in terms of nationality, citizenship, in/ex-clusion. One aspect that cannot be overlooked is the visible reliance upon historical reference: as self-emphatic or self-flagellating voices" (p.121). Thus, according to Chevereşan (2013), intertextuality in Native Speaker plays a significant role in the protagonist's understanding, interpretation and adaptation of historical texts that shed light on his socio-cultural position. Lee's instances of intertextuality can be grouped under four main categories: The Whitmanian preface, Shelley's poem, the Korean folksong and the use of the Korean language. As seen, the 
incidents of intertextuality stand in parallel as two texts carry the spirit of Western culture, while the other two maintain that of the Eastern. The investigation of these instances attempts to shed light on the reasons for revisiting these texts and how they help in constructing the KoreanAmerican cultural experience.

\subsection{The Whitmanian Preface}

Lee begins his discourse with two lines from Whitman's "The Sleepers". These are the first two lines of section 4 from the 8-section poem.

I turn but do not extricate myself,

Confused, a past-reading, another, but with darkness yet. (Lee, 1995, p. xi).

In his poem "The Sleepers", Whitman calls for universal empathy that lets human beings identify with one another so that they share the same dreams. In the first two sections, the speaker wanders through the night until he comes across a group of speakers from all walks of life. However, they are all grouped in one place and they are all asleep. The speaker identifies with these people as he sleeps among them and begins to dream their dreams. In section three, the speaker sees a white swimmer struggling against the ocean waves. The speaker implores the waves not to kill him, but it all goes in vain as the swimmer is eventually killed by the strong currents.

Section four begins with the speaker's lamentation as he tries to 'extricate' himself from the unfortunate incident that takes place at the shore. The ship is wrecked and there are no survivals. The speaker is helpless and can only wait for the next day to bury the bodies.

The following sections celebrate the spirit of unity. This is seen in section five where a flashback brings the speaker to the time of General Washington's speech as he grieves over the Brooklyn soldiers. In section six, the scene changes to that where the speaker's mother waits for a Native American girl who never shows up. The general's love for his American soldier with their different backgrounds and the mother's spiritual bond with the Native American girl pave the way for the orderly world depicted in section seven. In section eight, there is harmony and unity. 
Thus, the choice of poem is significant because the American classic invites cosmopolitan perspectives where all differences are blurred (Corely, 2004). In addition, it questions that the novel presents the ideal America that Whitman calls for. Instead, the novel presents an America where Asians are still viewed as outsiders and their works as "unreliable, treacherous. . . infiltrating the nation to observe 'us' from within, on the sly, illegally" (Moraru, 2009, p. 75). The kind of America Whitman calls for in his poem is one where "The Asiatic and African are hand in hand, the European and American are hand in hand" (Whitman, 2004, p. 131); however, in his novel, Lee sends the implied message that this vision is not at all shared by the Americans.

As the choice of text is now clear, the choice of lines should be considered from two aspects: their position in the poem and their significance. The chosen lines lie in the middle of the poem as they are preceded by the speaker's attempt to identify with the different people on the one hand, and with the harmonious united world depicted in the rest of the lines. This mediating position could be seen as Lee's depiction of a caught-in-the-middle situation, where immigrants are attracted to the American vision, but they find that it was not yet achieved. This pessimistic view can be contrasted with the choice of only two lines preceding the tragic ending facing the swimmer and the ship. This optimistic selection shows how Lee still hopes for an America where outsiders do not have to go through the painful experience of death in order to reach the harmony desired. Therefore, this instance of intertextuality allows Lee to revisit the American classical work and to offer his own interpretation, which renders Lee an "insider" who writes within "insider America and its tradition" (Moraru, 2009, p. 74).

It is worth mentioning that the concept of the shipwreck is further explored in the course of the novel as Lee refers to the incident of the Golden Venture incident that took place in 1993. The protagonist narrates

The next story is about a small freighter that runs aground off Far Rockaway in the middle of the night. The boat carries around fifty Chinese men who have paid $\$ 20,000$ each to smugglers to ship them to America. Men are leaping from the sides of the boat, clinging to ropes dangling down into the water. Rescue boats bob in the rough surf, plucking the 
treaders with lopped gaffs. The drowned are lined up on the dock beneath canvas tarps. The ones who make it, dazed, soaked, unspeaking, are led off in a line into police vans. (Lee, 1995, p. 229).

Corely (2004) argues that "within the novel, the comparison of the Golden Venture scene to Whitman's poems seems to link the spectacle of immigration to universal experiences of human suffering" (p. 74). The Chinese are presented as struggling immigrants who are rejected by the land. Since the ending here is altered - since there are survivors, it could be assumed that Lee hopes for a different ending. The link between the poem and the incident could be seen as a request for the American audience to adopt a vision similar to the one depicted in Whitman's "The Sleepers".

\subsection{Shelley's Poem}

Another western reference is brought about by intertextualizing three lines from Shelley's lyrical drama Prometheus Unbound. Henry, the Korean-American protagonist and narrator, remembers how he had to recite these three lines as language practice while attending elementary school in America.

Till, like on in slumber bound,

Borne to Ocean, I float down, around,

Into a sea profound, of ever-spreading sound. (Lee, 1995, p. 217).

In these lines, Asia, Prometheus' love interest, sings of a dream where she floats the ocean of sounds. In this part, Asia is responding to a dream of another character's dream where Prometheus was heard calling for Asia. In this song, Asia dreams of riding the sea to follow Prometheus.

The significance in choosing these lines lies in the fact that they tell of a Greek character who curses Jupiter and then pities him. This act of individuality is always seen as the base of human civilization in western literature canon. Thus, Lee's revisiting this text could also be seen as a way of showing that as an insider he is has a right to his own interpretation. In addition, the fact that this song is sung by a character named Asia, should be significant; her calling for Prometheus could symbolize Asian immigrants who call for Prometheus's promises to humanity, or for America's 'the brand of culture'. 
On the other hand, the context of this intertextuality and Henry's view of these lines present the meaning of the poem from a very different lens. Henry has to reluctantly recite these lines per the instructions of his class teacher who is described as "that ancient chalk-white woman" who carries a "a polished fruitwood stick" (Lee, 1995, p. 217). The link between the white teacher and the stick could be seen as a symbol of the white authority in America. As Henry is asked to recite, he stumbles, chokes and quivers, which shows how afraid and worried he seems against this white supremacy. By comparing these feelings to that of the dreamlike state in Asia's song, it is clear that Lee offers an opposite view of the image 'floating in an ocean of words'; instead of the harmony Asia feels, Henry feels lost and anxious.

This instance of intertextuality provides Lee with a chance to add his own interpretations to a well-established piece of Western classical poetry. This grants him the privilege of an insider who has the freedom to interpret works in his own way and the privilege of approaching his readers with a familiar work through which he can share his perspectives of things.

\subsection{The Korean Folksong}

Parallel to the reference to Western texts, Lee introduces his readers to the Korean cultural heritage through a folksong. The song tells the story of a "young man who decides to leave his family's farm and go to the city to make his fortune" (Lee, 1995, p. 277). After working for eighteen years, the man harvests success as he becomes "prosperous and wealthy" (Lee, 1995, p. 278). One day he hears of a death in his home village, and after investigation, he finds that it is his mother's funeral. Feelings of guilt soon overwhelm him for abandoning his family. He goes back to the village only to find out that his father had died long ago and that his family had suffered from debts.

This folksong can be seen as significant for a number of reasons, but first it is important to contextualize it occurrence in the discourse. The discussion of Korean folksongs takes place as the Korean American senator, Kwang and the protagonist, Henry are sitting in Kwang's basement where most of the work for Kwang's campaign for mayor takes place. This is after the arson at Kwang's office and the death of Eduardo 
and Helda, one of his staff members and the cleaning lady, respectively. This career setback is fueled by the media that favors Kwang's opposition. Thus, this is a very difficult moment for Kwang who feels rejected after all his hard work. As he becomes more involved in the talk about Korean folk songs, Henry observes that his accent begins to get "thicker and heavier" to the extent that Henry has "some trouble understanding him" (Lee, 1995, p. 277). While Kwang's English was described as 'beautiful' and 'formal', it is now characterized by a heavy Korean accent. This could be translated as a case of someone who aspires to a culture and so speaks its language beautifully and formally, but as this culture fails him, he loses his beautiful language and requests sanctuary from his native culture. This process is metaphorically accomplished through the Korean folksong.

While Henry attempts to sing the Korean folksong "Arirang", the unofficial Korean anthem, Kwang accuses him with cheating saying "You're cheating is sweetness" (Lee, 1995, p. 277). This illustrates the fact that his cry for his native culture gives a taste of sweetness to the song; something that Henry lacks. This is further emphasized when he signs as he shuts his eyes tight the way old pray with "their fearsome bouts of concentration on display, ferociously" (Lee, 1995, p. 277). This puts the folksong on an equal footing with the spiritual act of praying, which strengthens its significance in Kwang's heart; he sees it as a spiritual recharge against all the negative energy he is receiving from his new culture.

As for the story narrated in the song, the significance can be seen from two different angles. First, the melodramatic saga reflects the immigrants' troubled conscience as they leave their homelands behind; even becoming successful does not make up for leaving their family for material pursuits. Similarly, Kwang has traveled and has worked hard to make his way into the American land, but after the short success, he suffers knowing that his contact with his native land is lost just like the main character in the song.

The second angle provides an opposite yet valid interpretation; not only does Kwang cry for his old home, he is also lamenting the fact that he cannot feel at home at his new home. That is, the fact that he loses all contact with his old home showcases that his current place is his new 
home, where he leads a life with his family and friends and where he has a career. Crying for the old place shows how he lacks the feeling of belonging and security he should have acquired long ago. Thus, the Korean folksong not only shows the struggle of immigrants, but implies the homelessness that accompanies the second culture's rejection of immigrants as well.

These two contrasting interpretations - crying for the motherland and crying over the new land - renders Lee's employment of intertextuality significant in more ways than one. As it introduces the readers to the Korean culture, it acquaints them with the struggles of immigrants. At the same time, it shows how lost these immigrants feel as they are rejected by the only home they have now.

\subsection{Use of the Korean Language}

Intertextuality in this section will not be viewed as the integration of another text, but rather another language system. There are many instances in the novel where Lee introduces Korean words and expressions, sometimes even without translation. This intertextuality of languages highlights Lee's perspective of juxtaposition of cultures.

First, Lee introduces many Korean words that reflect Korean concepts or cultural items. For example, the first Korean word introduced in the discourse is 'ggeh' which he explains as a "money club in which members contributed to a pool that was given out on a rotating basis" (Lee, 1995, p. 46). This word is repeated more than once throughout the novel. It is introduced first as Henry explains how his father found Korean support to build his chain of stores. Then it is associated with Kwang, who runs a 'ggeh' to help Koreans in America. Interestingly, this 'ggeh' will be used as one of the ways American media and Kwang's American rival employ to bring Kwang down, which explains how Americans do not understand the nature of the 'ggeh' or its significance to the Koreans. This shows that Lee's introduction of the Korean word could be due to its equivalent absence.

Other Korean words that refer to items of the Korean cuisine are introduced as cultural specific items that acquaint the reader with the Korean culture. Lee (1995) presents some of these words are introduced with translations such as "namool . . . prepared vegetables" (p. 72), "soju . 
. . clear liquor made from potato" (p. 176), "go-choo pajun ... hot pepper and scallion fritters" (p. 177) and "ban-chahn ... the savory half dishes of vegetables and fish" (p. 293). On the other hand, Lee (1995) presents some items without translation such as "kalbi" (p. 176), "bulgogi" (p. 176), "kimchi" (p. 77) and "on myun" (p. 296). The choice not to translate these words could be interpreted in two ways: first, he assumes his readers' familiarity with these items; second, he wishes to arouse his readers' curiosity toward these items.

Some Korean expressions are introduced over the course of the novel. For example, Lee (1995) introduces his reader to the expression "ghopsul muh-ree" in "I was young that his ghopsul muh-ree showed the great vigor" without translation (p.126). This expression literally means 'curly hair'. The fact that Lee does not provide his readers with a translation to this expression that describes Henry's father highlights his intentional attempts to present Henry's father as an image that carries Korean connotations, even if they are mysterious to the American readers.

Another expression is "oorhee jip . . . our house" (Lee, 1995, p. 136). This expression is used by Kwang to refer to his house where he frequently holds informal gatherings with his staff members. The possessive adjective 'our' does not only refer to how Kwang's hospitality, it is actually how a house is usually modified in the Korean language. Even if one lives in a studio apartment, they would refer to their home as 'our house'. This collective nature of the adjective could be related to notions of respectability or to Eastern view of the world. Eastern thought dictates unity in its view with the society and the world. Each social member looks at how they can fit into the big machine of society. Thus, a house is not an individual property, but rather a collective one. The individualistic approach to viewing the world, which is adopted by most Western societies, would suggest individual ownership; this is why the expression 'my place' or 'my house' would be more common in the English language. Thus, the retention of the Korean expression here implies the different world view of the same aspect.

Another expression that is mentioned without translation is "yacheh gag eh", which is introduced as part of Kwang's speech to the Koreans in America; he says "own your store, your yacheh gag eh that you have built 
from nothing" (Lee, 1995, p.142). It is clear from the context of the speech that Kwang wants the Korean to proudly own the yacheh gag eh, with every meaning of the word and without any American interference. A literal translation would be a 'vegetable store', but then it would suggest American menial associations with inferiority, so retaining the Korean version makes it more inclusive and more appreciated by the Korean addressee.

Second, some Korean expressions and phrases are introduced as instances of characters communicating in Korean. For example, as Henry first steps into Kwang's office, he is greeted by the Korean phrase 'Ahnyoung-ha-sae-yo", as he explains that "[a]lmost everyone on the staff seemed to have at least a rudimentary knowledge of the language and customs, how to say hello and goodbye and please wait a moment" (Lee, 1995, p. 130). In the novel, it is mentioned that Kwang mainly depends on the Korean votes to win his elections; as a result, he needs to show his Korean supporters that through him and through his staff members there is a chance to reconnect with the Korean culture. The use of the Korean language for basic communication is thus contextually valid.

Moreover, other instances of Korean dialogical interaction are also shown when Henry speaks to Kwang's elder son. This shows that Kwang raises his children to speak in Korean while they are at home. This could be his way of maintaining the culture. Thus, Kwang's success in America does not represent his dissolving into the culture, but rather his retention of his Korean origin within the American society. America's rejection of this double identity standard is seen in his short-span career and his dramatic downfall.

The last instance of communication is introduced when Henry tells the Korean restaurant owner "gaen-cha-nah" to which "she doesn't seem to hear me, as if not understanding, and she goes" (Lee, 1995, p. 269). In this incident, Henry is at Korean restaurant, at first he pretends that he does not speak Korean, but as he responds in Korean at last, the Korean restaurant owner does not understand him. This could summarize Henry's life in America where he has tried to belong all his life to the American culture, and as he finally realizes that he does not fit and accordingly wishes to return back to his Korean origin, he finds that he 
does not belong there either. Thus, this little incident may appear insignificant, but in fact it is loaded with the marginalized immigrants' struggle in America.

Third, some words and phrases are associated with Henry's parents who as understood from the novel always speak to him in Korean. While most of their words are translated, some are transliterated. For example, when Henry returns drunk for the first time, he narrates how his father the next day sits with him, offers him a drink and asks him to "Mah-shuh . . . Drink" (Lee, 1995, p. 69). His father's attitude reflects the Korean tradition of how fathers take it upon themselves to teach their children, especially their sons as they come of age how to drink alcohol. Having low tolerance of alcohol is seen as a sign of weakness and so it is the father's job to teach their sons how to avoid such a flaw. Thus, the Korean version of the imperative 'drink' carries more than just a moment of bonding; it is a maintenance of tradition.

Another expression that is associated with Henry's memories of his father is "In-jeh . . . Now" (Lee, 1995, p. 69). Henry remembers how he used to wash bug screens with his father and how they would play and pretend to be shooting each other. The word 'now' would start the battle. This happened when Henry was still a child, but the vivid memory signals how momentous it must have been. This memory was of a time when Henry did not have to worry about the conflict between culture, and recalling this memory now means how he wishes for this time to come back.

When Henry moves out from his father's house to live at Lelia's apartment after their marriage, his father would call him every summer to ask "Ya, oh-noon-guh-ya", although no translation is offered, the meaning is implied from Henry's answer as he says, "yes we were coming" (Lee, 1995, p. 94). This instance of intertextuality could be seen as Henry's father asking his son to come to come visit his Korean father. In other words, the Korean phrasing could be viewed as a request for Henry to pay more attention to his Korean side.

The last intertextual incident associated with Henry's father is given as he comments on the news of some African American causing trouble; he says "egoh jeom ba, tihgee seki-nom mehnal nah-wandah . . look at this, 
everyday these black sons of bitches show up" (Lee, 1995, p.182). Despite Henry's father lack of interest in what goes on in America, such news provokes him to give this comment, which Lee chooses to maintain in its Korean voice. Two questions are raised here, what provoked Henry's father to give such a comment? And Why does Lee present this comment in Korean transliteration rather than a translation as usual? By looking at the trouble makers, it is clear that they are African American, another marginalized group who struggle to be acknowledged in America. Their cause of trouble could be their way of calling attention. Mr. Park's reaction could be seen as his identification with their problems and his empathy of how they feel, but at the same time his comment shows his rejection of their behavior. Thus, this private feeling had to be conveyed in Korean so that it carries the spirit of exclusion that characterizes those who witness the struggle of marginalization.

As for Henry's mother, she is only associated with one instance of intertextuality. At one point, she teaches her son a Korean proverb that says "San konno san itta . . . over the mountains there are mountains" (Lee, 1995, p.309). The Korean is an obvious choice to maintain the cultural value of the proverb. The proverb shows that life is an endless struggle, and as one crosses over a mountain, another mountain comes to view. Although the message conveyed is universal, the Korean origin had to be maintained.

\section{Conclusion}

Thus, the multiple instances of intertextuality highlight networks of meaning created through the reference to the different texts. While some are employed to summon what they stand for, others are introduced as bridges for Lee's different perspectives and views.

This study of intertextuality in Native Speaker as a cultural practice thus concludes that Korean immigrants constitute a marginalized stratum of the American social structure. Henry's revisiting of the American and the British canonized classical works, the Korean folksong and the Korean Language system reflect his struggle with his hybrid identity. At the end, he reaches the conclusion that he is a product of both cultures and that he needs to be accepted as a hybrid rather than a pure Korean or a pure American. As Henry realizes that he can never be a native speaker of 
American English nor Korean, he wishes to be acknowledged for who he is. Intertextuality was thus a valid means by which Lee managed to articulate the views of a Korean-American in American and to call Americans to embrace the promoted image of plurality and multiculturalism and accept him for who he is. 


\section{References}

1. Allen, G. (2000). Intertextuality. London: Routledge.

2. Bakhtin, M., \& Medvedev, P. N. (1978). The formal method in literary scholarship: A critical introduction to sociological poetics. Baltimore: Johns Hopkins University Press.

3. Barker, C. (2002). Making sense of cultural studies: central problems and critical debates. London: Sage Publications.

4. Barthes, R., \& Heath, S. (1977). Image, music, text. New York: Hill and Wang.

5. Chevereşan, C. (2013). Asian-Americans in New York: Two Men's Adventures in Immigrant-Land. Arcadia, 48(1), 116-134. DOI:10.1515/arcadia-2013.0005

6. Corley, L. (2004). "Just another ethnic pol": Literary Citizenship in Chang-Rae Lee's Native Speaker. Studies in the Literary Imagination, 37(1), 61-81.

7. Culler, J. (2000). Literary theory: a very short introduction ( $2^{\text {nd }}$ ed.). New York, NY: Oxford University Press.

8. Eagleton, T. (2000). The idea of culture. Oxford: Blackwell.

9. Eco, U. (1979). The role of the reader: explorations in the semiotic of texts. Bloomington: Indiana University Press.

10. Hartley, J. (2003). A short history of cultural studies. London: Sage Publications

11. Kristeva, J. (1980). Desire in language: A semiotic approach to literature and art. New York: Columbia University Press.

12. Kristeva, J. (1986). Word, Dialogue and Novel. In Toril Moi (ed.) The Kristeva Reader (34-61). Oxford: Basil Blackwell.

13. Lee, C. R. (1995). Native speaker. London: Granta Books

14. Moraru, C. (2009). Speakers and Sleepers: Chang-Rae Lee's "Native Speaker," Whitman, and the performance of Amerincanness. College Literature, 36(3), 66-91.

15. Saussure, F. (1959). Course in general linguistics. New York: Philosophical Library.

16. Whitman, W. \& Warner, M. (Ed.) (2004). The portable Walt Whitman. London, England: Penguin Books. 